\title{
ACTION RESEARCH IN DESIGNING AND IMPLEMENTING COURSES OF ENGLISH FOR LEGAL PURPOSES
}

\begin{abstract}
English for Legal Purposes (ELP) appears to be gaining popularity and acquiring a new dimension in many countries. An increasing number of legal professionals (i.e. law students and legal practitioners) consider their General English satisfactory but desire to learn the language of their professional domain, as they believe it will bring them improved job prospects in the future. There are some aspects of ELP teaching that can be both a hindrance and a challenge for ELP teachers. These include the lack of curricula for teaching Legal English at tertiary level institutions and the restricted number of teaching resources and guidelines with reference to teaching Legal English available on the market. This article draws on the outcomes of a three-year research project, which was undertaken to design, implement, and evaluate an ELP programme for adult professionals. The research project was conducted among 293 legal professionals in Poland and took the form of an action research model - a research tool that is not often exploited by scholars despite its unquestionable value.
\end{abstract}

Keywords: English for Legal Purposes (ELP), action research, legal professionals, syllabus, needs analysis.

\section{Introduction}

One may pose the question: what, in fact, is Legal English? How does it differ from Business English, Medical English etc.? Numerous researchers (Bloor and Bloor 1986; Corder 1993; Pieńkos 1999; Coxhead and Nation, 2001; Davies, 2001; Basturkmen, 2006) have undertaken a discussion on the notion of language for specific purposes (Legal English is definitely one); however no uniform definition has been elaborated. Over the years researchers have also attempted to define the notion of Legal English. Mellinkoff (1963), for example, noted that Legal English contains 'distinctive words, meanings, phrases, and modes of expression'. Eades (2010: 197- 


\section{Halina Sierocka}

207) describes it as "a kind of "insiders" language, similar to the way in which computer technicians might discuss your computer problems, in their specialised register, in front of you'. The aforementioned definitions could however also refer to other varieties of English like Technical or Medical English, not only to Legal English. Cao (2010: 78) is more precise and defines legal language as 'a variety of language appropriate to different legal occasions and legal situations of use and appropriate to those different legal situations of use'. She also highlights that legal language includes language of the law, language about law, and language used in legal communicative situations. On the other hand, numerous scholars (Block 1986: 169174; Bhatia 1993; Gibbons 2004; Haigh 2004; Ingels 2006; Schane 2006; Frade 2007; Jopek-Bosiacka 2008; Bhatia 2010; Bhatia and Bhatia 2011) endeavour to define the notion of Legal English by discussing its distinctive features, such as accuracy/precision, clarity, ambiguity or its unambiguity, specialisation, conservatism, and complexity. Even though in some cases, specificity and complexity of a language variety can be valued (as in the study of poetry) with reference to Legal English, this complexity and uncertainty poses obstacles in teaching and learning. In addition, lack of guidelines for Legal English teachers who frequently do not possess a legal background and legal terminology or lack of teaching materials or resources for Legal English teachers dishearten them to take up teaching Legal English.

\section{Context and the purpose of the research}

The aim of the research project was to design, implement and evaluate a curriculum of Legal English for adult professionals. A curriculum is understood here as a teaching programme for a particular course for a particular group of learners in a particular context. The author wanted to examine the target group's (i.e. legal professionals) needs and on the basis of the findings create a model course of English for Legal Purposes which would enable learners of Legal English to develop the necessary skills for their profession, as well as to expand their range of Legal English vocabulary and to gain greater confidence in that field. Teachers of Legal English would, on the other hand, benefit from a ready-to-use model of a Legal English curriculum. The importance of this issue results from the fact that there is an exponential interest in English for Specific Purposes as General English appears to be insufficient for effective communication between professionals. A further reason for undertaking the 
research was the lack of curricula for teaching Legal English at a tertiary level institution in Poland and the restricted number of teaching resources and guidelines with reference to teaching Legal English available on the market.

\section{Research methodology}

\subsection{Approach to data analysis}

For the purposes of this research project, an action research model was adopted. Despite its unquestionable value it is a very time-consuming and complex research instrument, hence is not often exploited by scholars. The study done by Potocka \& Author (2013) who reviewed research methods used by ESP academics for pedagogical and methodological issues indicated that the action research model was implemented only three times in 69 studies examined, whereas questionnaires, for example, were used 39 times.

As far as a definition of action research is concerned, Koshy (2005: 9) perceives it as:

...a constructive enquiry, during which the researcher constructs his or her knowledge of specific issues through planning, acting, evaluating, refining and learning from the experience. It is a continuous learning process in which the researcher learns and also shares the newly generated knowledge with those who may benefit from it.

Sagor (2007: 4) and Schmuck (2009: 1) approach the definition of action research in a similar way, the latter additionally pinpoints the differences from traditional research (see Table 1 ).

Komorowska (2006: 56), Mertel (2006: 2) and Sagor (2007: 4) agree that action research is a four - stage process, even though their explanation of the particular stages differs to some extent. The stages can be described as:

Stage 1: The Planning Stage which normally includes the identification of a problem, gathering information, reviewing the related literature and developing a research plan.

Stage 2: The Acting Stage which typically encompasses the implementation of the plan and collecting the data.

Stage 3: The Developing Stage during which the collected data is interpreted and an action plan is prepared.

Stage 4: The Reflecting Stage where the outcomes are disseminated, and finally, the research process is reflected upon. 
Table 1

Comparison of two research types (Schmuck 2009: 1)

\begin{tabular}{|l|l|}
\hline \multicolumn{1}{|c|}{ TRADITIONAL RESEARCH } & \multicolumn{1}{c|}{ ACTION RESEARCH } \\
\hline Explanation & Improvement \\
\hline Concerns search for explanation & $\begin{array}{l}\text { Concerns interventions for continuous } \\
\text { improvement }\end{array}$ \\
\hline Knowledge & Development \\
\hline $\begin{array}{l}\text { Seeks to build a body of accumulated } \\
\text { knowledge }\end{array}$ & $\begin{array}{l}\text { Seeks to foster development and planned } \\
\text { changes }\end{array}$ \\
\hline Experimentation & Perspectives \\
\hline $\begin{array}{l}\text { Obtains objective data from } \\
\text { a representative sample of subjects }\end{array}$ & $\begin{array}{l}\text { Collects trustworthy data on the multiple } \\
\text { perspective of particular individuals and } \\
\text { groups }\end{array}$ \\
\hline Universal & Local \\
\hline $\begin{array}{l}\text { Focuses on building universal theory } \\
\text { and valid generalization }\end{array}$ & Focuses on local change and improvement \\
\hline
\end{tabular}

Kemmis and Mc Tagart (2000: 595) emphasize that action research is a cyclical process where the above stages are replicated.

Another model for action research is proposed by Elliot (1991: 71). Its main components are presented in Figure 1.

\subsection{Sample}

The sample for the whole study comprised 293 legal professionals who were the target group for this research. For the purposes of the research, it was assumed that a legal professional is an adult professional involved in Legal English due to his/her work or study i.e. law students, lawyers, civil servants or academic teachers. Despite the fact that for many, a professional is a person who belongs to or engages in one of the professions (the Free Online Dictionary, 2010), the author included law students in the sample due to the fact that they are potential, prospective adult professionals interested in Legal English, so their needs and expectations should also be taken into consideration in planning a Legal English syllabus.

The research was carried out in three groups which are described as: research group 1, research group 2, and research group 3. Research group 1, comprised 250 representatives of the legal profession (112 civil servants, 8 academic teachers, 8 lawyers and 122 law students). Research group 2 
Action Research in Designing and Implementing Courses of English...

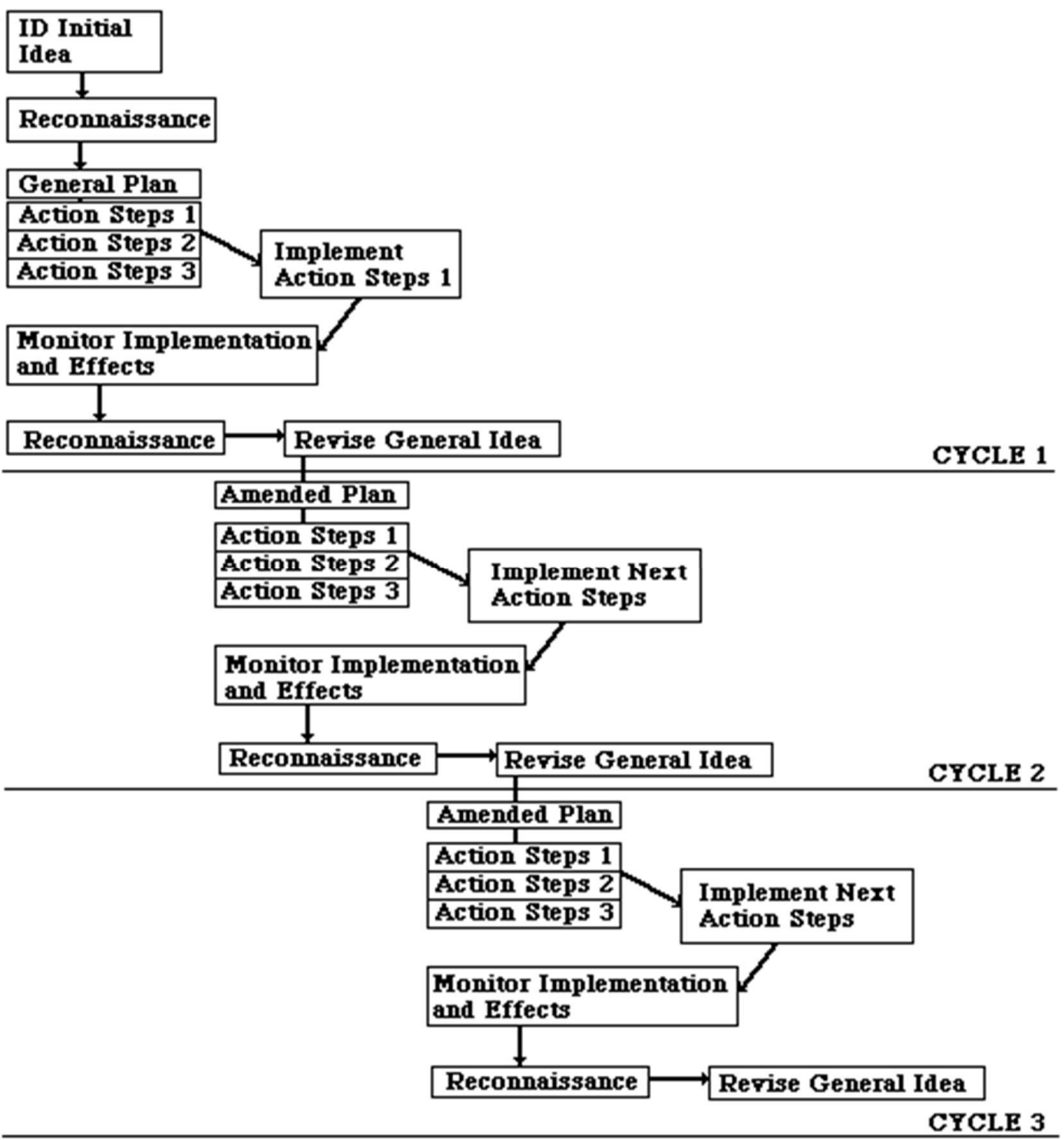

Figure 1. Elliot's research model

participated in Action Research Cycle 1 and consisted of 24 people (lawyers and civil servants) who attended the Legal English course that was piloted for the purposes of the research. Research group 3 related to Action Research Cycle 2 comprised 19 law students, being in different years of their studies, who also participated in the Legal English course.

\subsection{Research instruments and procedure}

The research project was designed on the basis of Elliot's action research model as in the author's opinion it suited the purpose of the research best. It comprised four stages which are presented in Table 2. 
Table 2

\section{Research design}

\begin{tabular}{|c|c|c|c|}
\hline \multirow{3}{*}{ 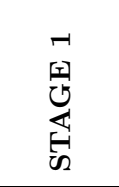 } & \multicolumn{2}{|l|}{ Initial idea } & \\
\hline & Fact-finding and analysis & $\begin{array}{l}\text { Needs analysis conducted among } \\
\text { research group } 1\end{array}$ & \\
\hline & \multicolumn{2}{|l|}{ General plan } & \\
\hline \multirow{5}{*}{ 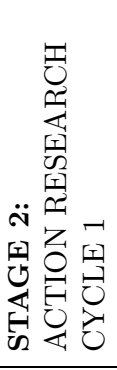 } & Action step 1 & $\begin{array}{l}\text { Conducting needs analysis among } \\
\text { research group } 2\end{array}$ & \multirow{3}{*}{ 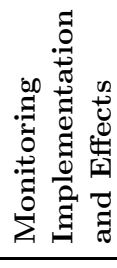 } \\
\hline & Action step 2 & $\begin{array}{l}\text { Designing a curriculum of Legal English } \\
\text { for research group } 2\end{array}$ & \\
\hline & Action step 3 & $\begin{array}{l}\text { Evaluating the effectiveness of the } \\
\text { curriculum }\end{array}$ & \\
\hline & \multicolumn{2}{|c|}{ Piloting Study (the analysis of the effects) } & \\
\hline & \multicolumn{2}{|l|}{ Revising General Idea } & \\
\hline \multirow{6}{*}{ 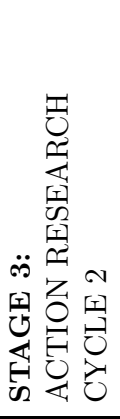 } & \multicolumn{2}{|l|}{ Amended plan } & \\
\hline & Action step 1 & $\begin{array}{l}\text { Conducting needs analysis among } \\
\text { research group } 3\end{array}$ & \multirow{3}{*}{ 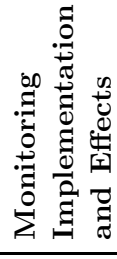 } \\
\hline & Action step 2 & $\begin{array}{l}\text { Designing a curriculum of Legal English } \\
\text { for research group } 3\end{array}$ & \\
\hline & Action step 3 & $\begin{array}{l}\text { Evaluating the effectiveness of the } \\
\text { curriculum }\end{array}$ & \\
\hline & \multicolumn{2}{|l|}{ The analysis of the effects } & \\
\hline & \multicolumn{2}{|l|}{ Revising General Idea } & \\
\hline 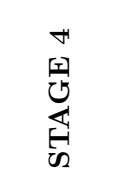 & Amended plan & $\begin{array}{l}\text { A model syllabus of English for Legal } \\
\text { Purposes }\end{array}$ & \\
\hline
\end{tabular}

\section{Research questions}

The research endeavoured to answer the following questions:

- What are the needs of research group 1, research group 2 and research group 3?

- How was the course implementation evaluated by research group 2 and research group 3?

- What are the implications of the study for a model curriculum of Legal English?

Some more specific questions were also posed depending on the stage of the research project: 
Action Research in Designing and Implementing Courses of English...

1. What are the aims of research group 1, research group 2 and research group 3 with reference to the Legal English course?

2. What are the expectations of research group 1, research group 2 and research group 3 with reference to the skills and abilities they may acquire during the course?

3. What are the perceptions of research group 1, research group 2 and research group 3 with regard to the Legal English course with reference to the course content?

4. What are the learning needs of research group 1, research group 2 and research group 3?

5. Is research group 1 homogeneous in their needs?

6. Did the pilot course based on the curriculum specifically designed to meet the students'(research group 2 and research group 3) needs allow them to make progress in the most required skills?

7. Did the students (research group 2 and research group 3) perceive any progress in other skills?

8. Was the course content appropriate / useful with reference to the legal discipline, the role of grammar, particular skills (research group 2 and research group 3)?

9. Did the students (research group 2 and research group 3) consider the teaching materials, types of exercises effective?

10. What changes should be introduced to the course of Legal English for future research groups (research group 2 and research group 3)?

The data essential to answering the research questions is both quantitative and qualitative in character. The needs analysis (Appendix A) carried out among all the research groups provided quantitative and qualitative data - firstly, the respondents answered the questions included in the research questionnaire, then the collected data were interpreted and conclusions drawn. One distinction has to be made here however. The needs analysis carried out among 250 legal professionals was to develop the guidelines for a curriculum framework for the target community i.e. legal professionals in general, whereas the needs analysis conducted and analysed at stages 2 and 3 was designed to reveal the needs and expectations of specific research groups towards the Legal English course in which they were about to participate. The teacher's reflections (e.g. with reference to teaching materials, pace of the lesson, the students' engagement in the activities) and the students' feedback during the course were both of a qualitative character but the post-course questionnaire (in which the participants were asked to comment on the course) was both quantitative and qualitative in nature (Appendix B). The students' feedback concerned the following aspects: 


\section{Halina Sierocka}

- the participant's self-evaluation with reference to the most required skills (the top three issues which were considered the most important by most of the respondents in the needs analysis were examined) concerning general aims, writing, speaking, reading, and listening,

- additional skills acquired during the course,

- the legal disciplines included in the course,

- the role of grammar in the course,

- the particular skills practised during the course,

- the evaluation of teaching materials,

- the types of exercises used during the course,

- the participants' remarks.

The students filled in the questionnaire and the data were interpreted. Finally, conclusions were reached after the completion of the cycles and further suggestions were made for improving the model curriculum.

\section{Results of the study}

\subsection{Stage 1 (Fact-finding and analysis)}

This part of the research was intended to analyse the needs of the target group (research group 1) in the context of designing and implementing courses in English for Legal Purposes. The research revealed that the main aim of research group 1 was to develop the necessary skills to communicate in their field of work. In the field of writing, a clear majority opted for learning how to write formal correspondence. In terms of speaking, it was difficult to ascertain an overwhelming preference as the following three issues were comparatively popular among the respondents: negotiations, giving opinions and speaking to the public. In the field of listening, two skills were of greatest interest i.e. listening to public statements and comprehension respectively. Understanding authentic materials as improving work skills took the first position by a large margin. Among a wide selection of fields, two legal disciplines were the most popular: Administrative Law and European Law, probably due to the fact that the respondents were either law and administration students, or civil servants who come across English and certainly Polish administrative law in their work. With regard to the role of grammar, most of the respondents stated that only essential grammatical structures should be included in the course. Speaking was considered to be the most helpful skill while learning a foreign language; however, three other skills came a close second: writing, listening and reading. Group work was considered the most effective way of studying 
a foreign language by research group 1 . With respect to learning aids, the media were selected as being most useful in the process of learning a foreign language. The great majority of research group 1 needed Legal English either to improve their skills and qualifications, or for work purposes. In general the students and the civil servants' preferences were matched; however, it can be stated that civil servants seemed to be more confident in expressing what their needs were while the students opted for those aspects which are more universal in the process of language learning; additionally there were some discrepancies in the field of listening and legal disciplines.

\subsection{Stage 2 - Action Research Cycle 1}

The aim of Action Research Cycle 1 of the project was to design, implement and evaluate a course of Legal English for research group 2. The data collected after Cycle 1 prompted some reflection over the process with regard to the successes and failures of its implementation and suggestions for further modifications. The areas of the author's reflections refer to:

- the extent to which particular skills were practised,

- the role of grammar,

- the disciplines of law,

- the groupings for activities during the course,

- the teaching resources.

\section{The extent to which particular skills were practised}

The results of the questionnaire (Appendix B) show that apart from writing, the participants thought that the extent to which other skills (listening, speaking and reading) were practised in the course was satisfactory: reading (88\%), speaking ( $75 \%$ ) and listening (75\%). 50\% of the respondents said that too little writing was practised in the course.

With regard to writing, it must be noted that all groups were quite reluctant to write anything. Assignments were given regularly, but as the course was not obligatory, the response was minimal; few of the participants submitted work (they excused themselves in terms of not having time, being overworked etc.). Nonetheless, the post-course questionnaire revealed that more written assignments were desirable. Observing the learners in class, the teacher discovered that they enjoyed working in groups or pairs; consequently more writing in class (as pair or group work) could solve the problem: they would feel more confident and their writing skills would improve. Still, there is a drawback to this proposition - it is time-consuming and the teacher would have to decide on whether to practise writing and economize 


\section{Halina Sierocka}

on some other aspects, or acknowledge the fact that the homework would not be done by all or most participants.

\section{The role of grammar}

Although the vast majority of the target group (77\%) expressed the need to revise essential grammatical structures, due to the fact that it was unclear whether there was enough time for all the planned modules, the teacher decided not to include any grammar in the course. The findings of the post-course questionnaire revealed that the participants did not feel this to be a problem. Therefore, it could be concluded that during a course of this kind, grammatical items may be treated as 'reminders' or as a 'language check' (without prejudicing the value of the course) rather than being a core element of the curriculum.

\section{The disciplines of law}

It is hard to perceive legal professionals as being a homogenous professional group as far as their legal interests are concerned. A needs analysis is, therefore, believed to be a central tool in identifying which areas of law need to be discussed during the course and to what degree. The post-course questionnaire revealed that the course of Legal English designed for research group 2 encompassed the desired disciplines of law to a satisfactory extent, except for Civil Law (29\% of the respondents remarked that this area of law should have been practised more). Nonetheless, it cannot be taken for granted that research group 3 or any other course group would need more Civil Law. This clearly results from the composition of the course group. Therefore, a needs analysis is essential before the course to establish the range of disciplines of law and the extent to which they are practised during the course.

\section{The groupings for activities during the course}

All types of groups for activities may be recommended during the course. Admittedly, in the needs analysis (Appendix A), the students mainly favoured group work and individual work, but as the outcomes of the postcourse questionnaire show, all methods of work were found to be either very effective or effective. However, it may be noteworthy that a lot depends on the teacher's flexibility and on the course group.

\section{The teaching resources}

As far as the teaching resources are concerned, they were highly rated by the participants, especially those based on source materials. Some respon- 
dents even underlined that more templates and official documents should be utilised by subsequent courses. A positive initiative would also be to include learners' presentations on the legal area they are interested in or specialise in, which would undoubtedly enrich the course content.

On the basis of conclusions drawn from the interpretation of the data obtained from the needs analyses (both for research group 1 and research group 2), the students' feedback during and after the course (research group 2) and the teacher's observations and reflections, the following modifications were suggested for Action Research Cycle 2:

- more emphasis should be put on practising writing,

- the extent to which grammar is taught during the Legal English course can be limited to language checks,

- the extent to which a particular discipline of law is discussed in the course should directly correlate with the prospective students' needs and expectations revealed in the needs analysis - a group of legal professionals is not as homogenous as it may seem to be,

- as Legal English vocabulary is quite complex, a greater variety of groupings for activities and teaching resources (also learner-generated materials) is recommended.

\subsection{Stage 3 - Action Research Cycle 2}

The aim of Action Research Cycle 2 was to design, implement and evaluate a curriculum for a course of Legal English for research group 3. The curriculum was designed and implemented on the basis of the results of the needs analysis (Appendix A), conducted among a representative group of legal professionals, the needs analysis performed before the course among research group 3 and the teacher's reflections after Action Research Cycle 1 of the present research project. The data collected during and after Action Research Cycle 2 indicated that the pilot course met the objectives set for the curriculum to a certain extent and further modifications are required. The conclusions result from the author's own reflections during the process of designing, implementing and carrying out the course and from the participants' suggestions. The areas in which the author considers that changes need to be implemented, include:

- the length of the course,

- the needs analysis,

- the extent to which particular skills were practised,

- the role of grammar,

- the teaching resources,

- the assessment. 


\section{Halina Sierocka}

\section{The length of the course}

The length of the course resulted from a logistical situation rather than from the teacher's decision. The academic year starts in October and November was the earliest opportunity possible for commencing the course for organisational reasons. Due to the fact that the group of learners comprised law students in different years of their studies, it was difficult to arrange the classes more often than once a week, which affected the course length. It can be argued that 75 teaching hours is definitely insufficient time to achieve all of the aims of the Legal English curriculum. This had an impact on the extent to which particular skills were practised, the role of grammar in such a course, and the extent to which progress was achieved.

\section{The needs analysis}

After two cycles of the research, it can be stated that a needs analysis is an indispensable element of a course in Legal English. As mentioned previously, no course group of legal professionals is identical - it may comprise, for instance, judges, tax advisors, civil servants or prosecutors - each group may be interested in different legal disciplines. The needs analysis helps to establish in what proportion and to what degree a particular discipline of law is discussed. A further conclusion following the two cycles of the research with regard to the needs analysis is that it would be useful to carry it out, not only before the course, but during the course as well. The participants themselves often do not know what they want before the onset of the course - the outcomes of a needs analysis conducted before the course might be different from the outcomes of a needs analysis conducted during the course, which is best seen with the example of writing in the second cycle. The needs analysis conducted before the course revealed that writing was considered to be the least important skill required in learning a foreign language, but the results of the post-course questionnaire demonstrated that the participants felt that more writing would have been desirable as, in their opinion, it had not been practised to a satisfactory extent. The question then arises - is this a problem with the skill itself (even in their native language, students often write little) or with the teacher's technique, or the fact that the participants' expectations did not match their needs?

\section{The extent to which particular skills were practised}

The degree to which a particular skill was practised during the course was considered as being satisfactory for reading (88\%) and speaking (69\%), but not with regard to listening. Even though $44 \%$ of the respondents felt that listening had been sufficiently practised, $31 \%$ stated that it had not. 
Writing, on the other hand, was considered to have been insufficiently practised (only $6 \%$ said that it was adequately done $-63 \%$ of the respondents claimed just the opposite). The outcomes of the needs analysis conducted before the course revealed that the participants considered it to be the least important skill; nevertheless, it can be concluded that participants of the Legal English course ultimately felt that they needed more practise in this area. In fact, the results are even more striking than after Action Research Cycle 1. The suggestions from the former evaluation concerning practising writing were, to some extent, incorporated into Action Research Cycle 2 (as far as possible given the limited number of teaching hours): more written assignments were given as part of homework and more opportunities for writing were made available in class. Neither solution was ideal. It was extremely difficult to enforce compliance with writing assignments, as the course was of a commercial nature (financed by the participants themselves) and not obligatory; consequently, few of the students submitted the writing assignments (on average $3-4$ out of 19). Writing practice during the classes took up a considerable amount of time and as a result the teacher had to compromise with regard to the teaching of other skills and limiting the course content. In consequence, providing for writing assignments as part of class work did not solve the difficulties around writing, as the participants of research group 3 perceived their progress as being at a lower level than the participants engaged in Action Research Cycle 1.

\section{The role of grammar}

One third of the participants declared that they were discontented with the fact that grammar was not included in the syllabus. This may seem surprising, taking into consideration:

- the limited number of teaching hours - there was not enough time to discuss all of the content areas adequately,

- the outcomes of the needs analysis carried out before the course among the group - vocabulary was considered more important than grammar,

- the specificity of the research group - one might think that law students who took their Matura (secondary school-leavers') exams not long ago would not like to study more grammar.

It can be stated that the role of grammar in a course of Legal English should be left to the teacher to decide. The teacher himself/herself would have to determine the proportion of time allocated between grammar and vocabulary taking into consideration the outcomes of the needs analysis conducted before the course, the length of the course and the participants' level of English. Some suggestions would be to include short revisions as 


\section{Halina Sierocka}

a part of homework - nonetheless, grammatical errors should always be corrected and explained.

\section{The teaching resources}

With reference to the teaching resources, one conclusion after both cycles is that any materials based on or adapted from authentic materials were evaluated as the most attractive and helpful while learning Legal English. The participants found templates, official documents or regulations very effective - moreover, they could use the resources in their work, which was an additional benefit. The glossaries prepared by the students in the first cycle were considered very useful, however, the presentations prepared by the participants not necessarily so - they were perceived as a kind of burdensome duty and as a result, most of the presentations were tedious and generic. Some of the learners did not want to present anything, and just prepared a set of exercises to do by the group in silence.

\section{The assessment}

It can be stated unquestionably, after Action Research Cycle 2, that participants require more testing - tests after each section of the course, regular quizzes on vocabulary, an-end-of-the-course examination. During the course for research group 3, the participants' progress was assessed by means of short quizzes on vocabulary and by an end-of-course test. This was evaluated as being insufficient. The demand for testing may not only result from the desire on the part of learners to have their progress evaluated, but it seems that assessment procedures can constitute a stimulus to learning the subject.

\subsection{Stage 4 - amended plan}

Several implications for a model curriculum for a course of English for Legal Purposes arise from the outcomes of the needs analysis carried out in the target group of 293 legal professionals (who participated in the research project) and the reflections after two cycles of the present Action Research. These are:

- legal professionals need Legal English for their work or studies,

- legal professionals want to develop the necessary skills to communicate in their profession,

- legal professionals especially want to master skills such as: writing formal correspondence, negotiating, giving opinions and speaking to the public, listening to public statements, listening for details and understanding authentic materials, 
- a needs analysis is a vital instrument in developing a curriculum of Legal English for a particular group as it helps to establish the particular group's target and learning needs,

- prospective students' needs and expectations, their level of English and the course duration affect the extent to which particular skills and grammar are practised and the extent to which particular disciplines of law are included in the course,

- a variety of teaching resources (especially based or adapted from authentic materials and learner-generated), groupings for activities and techniques makes learning effective and motivating,

- diverse forms of progress assessment are recommended.

\section{Discussion}

In summary, this research project shows that the target group's (research group 1) needs concerning a course of English for Legal Purposes include developing the necessary skills to communicate in their field of work, establishing and maintaining relationships through exchanging information as well as maintaining correspondence. In particular the target group desired to practise and improve such skills as: writing formal correspondence, negotiations, giving opinions and speaking to the public, listening to public statements and comprehension, understanding authentic materials. The needs were confirmed by the outcomes of the needs analysis conducted among research group 2 and research group 3 i.e. particular Legal English course participants. They reported that they believed that they had made observable progress following the pilot course. Therefore, it may be concluded that the course met the aims of the curriculum; however, the extent to which this was true was different for each research group. Moreover, the participants reported that they felt that writing was the skill that had been practised insufficiently. At the same time, the learners of both research groups had been reluctant to practise writing in and outside the class.

With reference to choosing disciplines of law, the preferences depended on a particular group's professional interests. The target group reported that their motivation lay in studying Administrative Law, European Law, General Features of the English Legal System and the Sources of Law, whereas research group 2 leaned towards Commercial and Company Law, Administrative Law, European Law and Criminal Law. Research group 3, on the other hand, considered Criminal Law, General Features of the English Legal System, Employment Law, Commercial and Company Law to be of central 


\section{Halina Sierocka}

importance. Therefore, a needs analysis before any course of Legal English is indispensable to select and grade the content of the syllabus.

The research confirmed that all group sizes for activities were considered effective by the learners despite some reservations before the course. In the needs analysis (Appendix A) conducted before the course both research groups expressed reluctance to work in pairs. However, the post-course questionnaire (Appendix B) revealed that, in fact, all groupings for activities were found either very effective or effective and remarkably, pair work was thought to be the most effective while learning Legal English.

All research groups (research groups 1, 2 and 3) recognised the importance of grammar in such a course; nonetheless, practising vocabulary was believed to be the priority. Undoubtedly, aids which provide primary source material such as the media, books and magazines or working with a native speaker were found most useful during the Legal English course. Regular and on-going assessment was appreciated and desired by the participants providing a continuous stimulus to learn Legal English. The needs analysis is a central and indispensable element of planning and implementing a curriculum of English for Legal Purposes. It helps to describe and estimate the target group's needs, expectations with reference to the aims, skills, course content and learning needs. Several implications for a model curriculum for a course of English for Legal Purposes arise from the outcomes of the needs analysis carried out in the target group of 293 legal professionals (who participated in the research project) and the reflections after two cycles of the present Action Research. These are:

\section{Conclusion and recommendations for further study}

In conclusion there are several issues concerning Legal English both of an academic and methodological nature that could be pursued as a consequence of the study.

The first issue concerns the evaluation of a model curriculum of Legal English. The model curriculum provided in the research project could be evaluated in the form of Cycle 3 of the action research (hence constituting a kind of continuation of the discussed research) or different evaluation techniques could be devised and implemented to verify the validity and effectiveness of the model curriculum of Legal English.

Another area worth considering is the concurrence of the target group's needs. As illustrated in the research, the perception of the course by law students and lawyers differed slightly. Even though both groups (law stu- 
dents and lawyers) are involved in law, their needs and expectations do not necessarily have to match. Research which could confirm or deny the concurrence of their needs with reference to Legal English would, therefore, be suggested.

In terms of the course length it is worth considering examining whether more focused courses with a limited number of teaching hours would be as effective as the recommended model. This issue might be quite critical for legal professionals who specialise in a particular legal discipline and either do not have time or any interest in participating in a course which comprises all legal disciplines.

As most ESP courses are designed for learners whose command of English is at least at the B1/B2 level of the Common European Framework of Reference, it might therefore, be possible to design, implement and evaluate a curriculum for a course of English for Legal Purposes at a lower level, for example A2 (according to CEFR) and examine its effectiveness and validity.

Finally, the issue of cooperative teaching (between language teachers and subject specialists) may be worth examining. Research could reveal whether this form of instruction is effective and feasible in teaching and learning the language for specific purposes.

The author hopes that the aforementioned research project and its outcomes have provided some insight into the challenges facing the Legal English instructor acting as a Legal English curriculum developer.

\section{R E F E R E N C E S}

Basturkmen, H. 2006. Ideas and Options in English for Specific Purposes. New York: Routledge.

Bhatia, V. K. 1993. Analysing Genre: Language Use in Professional Settings. London: Longman.

Bhatia, V.K. 2010. 'Legal writing: specificity. Specification in legislative writing: accessibility, transparency, power and control' in M. Coulthard and A. Johnson (eds.) The Routledge Handbook of Forensic Linguistics. Abingdon: Routledge.

Bhatia, V.K., and A. Bhatia. 2011. 'Legal discourse across cultures and sociopragmatic Contexts.' World Englishes. 30 (4): 481-495. DOI: 10.1111/j.1467971X.2011.01727

Block, D. 1991. 'Some thoughts on DIY materials design.' ELT Journal, 45 (3).

Bloor, T. and M. Bloor. 1986. Languages for Specific Purposes: Practice and Theory (occasional paper no. 19). Dublin: Trinity College. 


\section{Halina Sierocka}

Cao, D. 2010. 'Legal translation. Translating legal language' in M. Coulthard and A. Johnson (eds.) The Routledge Handbook of Forensic Linguistics. Abingdon: Routledge.

Corder, S. P. 1993. Introducing Applied Linguistics. London: Penguin. (Original work published in 1973).

Coxhead, A. and P. Nation. 2001. 'The specialised vocabulary of English for academic purposes.' in J. Flowerdew and M. Peacock (eds.) Research Perspectives on English for Academic Purposes, 252-267. Cambridge: Cambridge University Press.

Davies, A. 2001. 'The logic of testing Languages for Specific Purposes. Language Testing, 18: 133-147.

Eades, D. 2010. 'Using English in the Legal Process'in The Routledge Companion to English Language Studies, ed. by Janet Maybin and Joan Swann, 197-207.

Elliot, J. 1991. Action Research for Educational Change. Buckingham: Open University Press.

Frade, C. 2007. 'Power dynamics and legal English.' World Englishes, Vol. 26 (1): 48-61.

Gibbons, J. 2004. 'Taking Legal English seriously' in J. Gibbons, V. Prakasam, V. K. Tirumalesh and H. Nagarajan (eds.) Language and the Law. Hyderabad: Orient Longman Private Limited.

Haigh, R. 2004. Legal English. New York: Cavendish Publishing Limited.

Ingels, M. B. 2006. Legal English Communication Skills. Lueven: Acco.

Jopek-Bosiacka, A. 2008. Przektad Prawny i Sadowy. Warszawa: Wydawnictwo Naukowe PWN.

Kemmis, S. and R. McTagart. 2000. 'Participatory Action Research: Communicative Action and the Public Sphere' in: Denzin, N.K., Lincoln, Y.S (eds.): the Sage Handbook of Qualitative Research, 559-604.

Komorowska, H. 2006. Programy Nauczania w Ksztatceniu Ogólnym i Kształceniu Jęzkkowym. Warszawa: Fraszka Edukacyjna.

Koshy, V. 2005. Action Research for Improving Practice London: Sage Publications, Inc.

Mellinkoff, D. 1963. The Language of the Law. Boston: Little, Brown \& Co.

Mertel, C.A. 2006. Action Research Teachers as Researchers in the Classroom London: Sage Publications, Inc.

Pieńkos, J. 1999. Podstawy Juryslingwistyki: Jezzk w Prawie - Prawo w Języku. Warszawa: Oficyna Prawnicza. MUZA SA.

Sagor, R. 2007. Action Research Guidebook London: Sage Publications, Inc.

Schane, S. A. 2006. Language and the Law. London: Continuum.

Schmuck, A. 2009. Practical Action Research: A Collection of Articles London: Corwin Press. 
Action Research in Designing and Implementing Courses of English...

\section{APPENDIX A. NEEDS ANALYSIS}

I. What would you like to achieve during the legal English course? Please mark max. TWO most important general objectives of Legal English course.

\begin{tabular}{|l|l|}
\hline a) I would like to develop the skills necessary to communicate & \\
with other people in my trade & \\
\hline b) I would like to be able to participate in conversation related & \\
to everyday situations & \\
\hline $\begin{array}{l}\text { c) I would like to be able to establish and maintain relationships } \\
\text { through exchanging information }\end{array}$ & \\
\hline d) I would like to be able to have a free conversation & \\
\hline e) I would like to be able to keep up the correspondence & \\
\hline f) other: & \\
\hline g) it is difficult to say & \\
\hline
\end{tabular}

II. Which specific objectives within the skills given below are the most important to you?

Please mark the top THREE in field of WRITING:

\begin{tabular}{|l|l|}
\hline a) formal correspondence & \\
\hline b) informal, private correspondence & \\
\hline c) pleadings/statements of case & \\
\hline d) application letters, CVs, invitations & \\
\hline e) application forms and questionnaires & \\
\hline f) reports, proceedings, notices, memos etc. & \\
\hline g) other & \\
\hline h) it is difficult to say & \\
\hline
\end{tabular}


Please mark the top THREE in field of SPEAKING:

\begin{tabular}{|l|l|}
\hline a) negotiating & \\
\hline b) holding telephone conversations & \\
\hline $\begin{array}{l}\text { c) solving problems in particular situations (e.g. at the post office, } \\
\text { in a restaurant etc.) }\end{array}$ & \\
\hline d) giving opinions - agreeing and disagreeing & \\
\hline $\begin{array}{l}\text { e) discussing topics of interests (e.g. family, hobbies, travel- } \\
\text { ling etc.) }\end{array}$ & \\
\hline $\begin{array}{l}\text { f) speaking to the public (e.g. lectures, commercial presentations, } \\
\text { public speeches etc.) }\end{array}$ & \\
\hline g) others & \\
\hline h) it is difficult to say & \\
\hline
\end{tabular}

Please mark the top THREE in field of LISTENING:

\begin{tabular}{|l|l|}
\hline a) understanding telephone conversations & \\
\hline b) understanding TV or radio news & \\
\hline $\begin{array}{l}\text { c) obtaining necessary information in different situations (e.g. at } \\
\text { the hotel, at the railway station etc.) }\end{array}$ & \\
\hline d) understanding announcements and advertisements & \\
\hline e) listening for details & \\
\hline $\begin{array}{l}\text { f) listening to public statements (e.g. information, instructions } \\
\text { and warnings etc.) }\end{array}$ & \\
\hline g) other & \\
\hline h) it is difficult to say & \\
\hline
\end{tabular}

Please mark the top THREE in field of READING

a) understanding authentic materials (e.g. reading for gist and for details etc.) 
Action Research in Designing and Implementing Courses of English...

\begin{tabular}{|l|l|}
\hline b) searching for and understanding the particular information & \\
\hline $\begin{array}{l}\text { c) improving and revising the vocabulary on the basis of authentic } \\
\text { materials }\end{array}$ & \\
\hline d) understanding announcements and commercials & \\
\hline e) reading for gist & \\
\hline f) reading and following the instructions & \\
\hline g) reading for pleasure & \\
\hline h) other & \\
\hline i) it is difficult to say & \\
\hline
\end{tabular}

III. Which particular discipline of law is the most useful for you? Mark max. FOUR disciplines, please.

\begin{tabular}{|l|l|}
\hline a) general features of the English legal system & \\
\hline b) sources of law (e.g. the Constitution) & \\
\hline c) company (commercial) law & \\
\hline d) criminal law & \\
\hline e) European law & \\
\hline f) administrative law & \\
\hline g) employment (labour) law & \\
\hline h) public international law & \\
\hline i) financial law & \\
\hline j) civil law (family law, property law, intellectual property law, & \\
\hline inheritance law) & \\
\hline k) contracts & \\
\hline l) tax law & \\
\hline ł) other & \\
\hline m) it is difficult to say & \\
\hline
\end{tabular}




\section{Halina Sierocka}

IV. What is the role of grammar in such a course? Mark the appropriate answer, please.

a) grammar should be revised thoroughly

b) only essential grammatical structures should be discussed

c) such a course should cover no grammar at all

V. Which skill/skills is/are the most helpful for you while learning a foreign language? (more than one answer can be given)
a) listening
b) writing
c) reading
d) speaking
e) other

VI. Which is/are the most effective way(s) of studying? Mark max. TWO answers, please.
a) individual work
b) pair work
c) group work
d) the whole class work
e) other

VII. Which is the most important element of Legal English learning? Mark the appropriate answer, please.
a) grammar
b) vocabulary
c) pronunciation

VIII. What is the most helpful in the process of foreign language (including Legal English) learning? Mark max. TWO answers, please.
a) books, magazines and newspapers
b) the media ( $\mathrm{TV}$, radio and the Internet)
c) games \& puzzles
d) working with a native speaker
e) other

IX. Any suggestions and/or comments? 
Action Research in Designing and Implementing Courses of English...

\section{RESPONDENT'S PERSONAL INFORMATION}

\section{I am ...}

a) a civil servant / clerk

b) an academic teacher

c) a legal practitioner

d) a law student year

\section{I need Legal English}
a) in my studies
b) in my work
c) to improve my skills and qualifications
d) as a hobby
e) I don't need / won't need that - I study because I have to.
f) other

\section{APPENDIX B. POST-COURSE QUESTIONNAIRE}

\section{SKILLS}

After the course I could ...

1 - a little better 2 - to some extent better 3 - better 4 - much better 5 a great deal better

\begin{tabular}{|l|l|}
\hline GENERAL AIMS & \\
\hline - communicate with other people in my trade & \\
\hline $\begin{array}{l}\text { - establish and maintain relationships through exchanging infor- } \\
\text { mation }\end{array}$ & \\
\hline - keep up correspondence & \\
\hline
\end{tabular}

\begin{tabular}{|l|l|}
\hline WRITING & \\
\hline$\bullet$ keep up formal correspondence & \\
\hline$\bullet$ write projects & \\
\hline$\bullet$ write reports, proceedings, notices and memos & \\
\hline
\end{tabular}




\begin{tabular}{|l|l|}
\hline SPEAKING & \\
\hline$\bullet$ negotiate & \\
\hline$\bullet$ give opinions (agree or disagree) & \\
\hline
\end{tabular}

\begin{tabular}{|l|l|}
\hline LISTENING & \\
\hline$\bullet$ understand public statements & \\
\hline$\bullet$ obtain and understand details, & \\
\hline$\bullet$ understand TV or radio news & \\
\hline
\end{tabular}

\begin{tabular}{|c|}
\hline READING \\
\hline - understand authentic materials \\
\hline - search for and understand particular information \\
\hline $\begin{array}{l}\text { - improve and revise the vocabulary on the basis of authentic } \\
\text { materials }\end{array}$ \\
\hline
\end{tabular}

\section{OTHER SKILLS}

Did you improve any other skills? Mark the one/ones which you have considerably improved.

\begin{tabular}{|l|l|}
\hline - participating in conversations related to everyday situations & \\
\hline - discussing topics of interests & \\
\hline - keeping up an informal correspondence & \\
\hline - preparing briefs & \\
\hline - filling in application forms and questionnaires & \\
\hline - writing application letters, CVs, or invitations & \\
\hline - leading telephone conversations & \\
\hline - solving problems in particular situations (e.g. at the hotel, in & \\
\hline a restaurant, at the railway station) & \\
\hline tions, formal speeches) & \\
\hline
\end{tabular}


Action Research in Designing and Implementing Courses of English...

- obtaining the necessary information for different situations

- understanding announcements and advertisements

- skim reading

- reading and following instructions

- reading for pleasure

\section{LEGAL DISCIPLINES}

To what extent were the disciplines of law included in the Legal English course? Mark the appropriate box.

\begin{tabular}{|l|l|l|l|l|}
\hline \multicolumn{1}{|c|}{ Discipline } & Too much & Enough & Too little & No opinion \\
\hline $\begin{array}{l}\text { General features } \\
\text { of the English } \\
\text { legal system }\end{array}$ & & & & \\
\hline The sources of law & & & & \\
\hline Criminal Law & & & & \\
\hline Contracts & & & & \\
\hline Employment Law & & & & \\
\hline Civil Law & & & & \\
\hline Administrative Law & & & & \\
\hline Financial Law & & & & \\
\hline $\begin{array}{l}\text { Commercial and } \\
\text { Company Law }\end{array}$ & & & & \\
\hline International Law & & & & \\
\hline
\end{tabular}


Halina Sierocka

IV. ROLE OF GRAMMAR

What was the role of grammar in the Legal English course?

1. I think that grammar was corrected systematically

2. I think that grammar was not discussed and I am unsatisfied

3. I think that grammar was not discussed in the course and I am satisfied

\section{FOUR SKILLS}

To what extent were particular skills practised during the Legal English course?

\begin{tabular}{|c|c|c|c|c|}
\hline Skill & Too much & Enough & Too little & $\begin{array}{c}\text { I do not have } \\
\text { opinion }\end{array}$ \\
\hline Writing & & & & \\
\hline Reading & & & & \\
\hline Listening & & & & \\
\hline Speaking & & & & \\
\hline
\end{tabular}

\section{EVALUATION OF TEACHING MATERIALS}

Which teaching materials were the most useful and helpful in learning Legal English?

\begin{tabular}{|l|l|l|l|l|}
\hline \multicolumn{1}{|c|}{ Materials } & $\begin{array}{c}\text { Very } \\
\text { useful }\end{array}$ & $\begin{array}{c}\text { Quite } \\
\text { useful }\end{array}$ & $\begin{array}{c}\text { Not very } \\
\text { useful }\end{array}$ & $\begin{array}{c}\text { Not useful } \\
\text { at all }\end{array}$ \\
\hline $\begin{array}{l}\text { Leading course book "Business } \\
\text { Law" by Tricia Smith }\end{array}$ & & & & \\
\hline $\begin{array}{l}\text { Additional materials taken } \\
\text { from "International Legal } \\
\text { English" by A. Krois-Lindner }\end{array}$ & & & & \\
\hline The teacher's own materials & & & & \\
\hline Tests & & & & \\
\hline
\end{tabular}


Action Research in Designing and Implementing Courses of English...

\begin{tabular}{|l|l|l|l|l|}
\hline $\begin{array}{l}\text { Materials prepared by } \\
\text { participants during } \\
\text { course }\end{array}$ & & & & \\
\hline $\begin{array}{l}\text { Glossaries prepared by } \\
\text { participants during } \\
\text { the course }\end{array}$ & & & & \\
\hline Other & & & & \\
\hline
\end{tabular}

\section{TYPES OF GROUPINGS}

Which groupings for activities were the most useful and helpful in learning Legal English?

\begin{tabular}{|l|l|l|l|l|}
\hline \multicolumn{1}{|c|}{ Groupings } & $\begin{array}{c}\text { Very } \\
\text { effective }\end{array}$ & $\begin{array}{c}\text { Quite } \\
\text { effective }\end{array}$ & $\begin{array}{c}\text { Not very } \\
\text { effective }\end{array}$ & $\begin{array}{c}\text { Not effective } \\
\text { at all }\end{array}$ \\
\hline Working individually & & & & \\
\hline Working in pairs & & & & \\
\hline Working in groups & & & & \\
\hline Whole class work & & & & \\
\hline
\end{tabular}

